\title{
Retroçekal Akut Apandisitte Cerrahi: Açık mı? Laparaskopik mi?
}

\author{
Surgery for retrocecal acute appendicitis: Open or laparoscopic?
}

\author{
Uzm. Dr. UYSAL Erdal', Doç. Dr. KIRDAK Türkay ${ }^{2}$, Yard. Doç. Dr. DOKUR Mehmet ${ }^{3}$, Yard. Doç. Dr. \\ BAKIR Hasan", Uzm. Dr. GÜRER Ahmet Orhan ${ }^{5}$, Yard. Doç. Dr. Başar Aksoy ${ }^{6}$, Uzm. Dr. IKIDAG A. \\ Mehmet $^{7}$, Prof. Dr. YÜZBAŞIOĞLU, Mehmet Fatih ${ }^{8}$
}



\section{öz}

Amaç: Akut apandisit, akut batına sebep olan en yaygın hastalıktır. Cerrahlar giderek artan oranda laparoskopik cerrahi tedaviyi akut apandisitte de tercih etmektedir. Ancak jeneralize peritonit, komplike apandisitlerde ve retroçekal apandisitlerde halen laparoskopik cerrahide kararsızlık yaşanmaktadır. Çalışmamızda retroçekal apandisit nedeniyle laparoskopik apendektomi ve açık apendektomi uygulanmış hastaların karşılaştırılması ve laparoskopinin bu vakalarda etkinliğini belirlemek amaçlanmıştır.

Gereç ve Yöntem: Akut retroçekal apandisit nedeniyle laparoskopik apandektomi ve açık apandektomi uygulanan 26 hasta çalışmaya alındı. Operasyon süresi, hastanede yatış süresi, komplikasyonlar ve maliyetler not edilerek karşılaştırıldı. Veriler ortalama \pm Standart sapma (SD) olarak verilmiştir.

Bulgular: Ortalama operasyon süresi laparoskopik apandektomi ve açık apandektomide sırasıyla 75 20.3

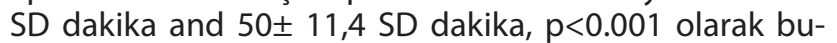
lundu. Ortalama hastanede kalış süresi laparoskopik apandektomi ve açık apandektomide sırasıyla 27.64 13 SD and 28.72 \pm 10.9 SD saat, $p>0.05$ olarak bulundu. Toplam maliyet açık apandektomi grubunda anlamlı olarak azdı. Ortalama total maliyet açık apandektomi ve lapa-

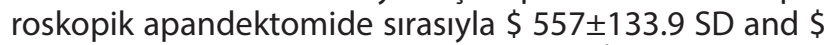
$806 \pm 264.3$ SD, $p<0.01$, olarak bulundu. Intraabdominal apse oranı her iki grupta benzerdi. Yara enfeksiyonu oranı ise bir hasta laparoskopik apandektomi, dört hasta açık apandektomi grubunda bulundu, $\mathrm{p}=0.012$.

Sonuç: Laparoskopik apandektomi retroçekal akut apandisitin tedavisinde güvenli ve uygulanabilir bir yöntemdir. Düşük yara enfeksiyonu oranı avantaj olarak görülmektedir. Açık apandektomi ise operasyon süresi ve total maliyet açısından laparoskopik apandektomiye göre üstün görülmektedir.

Anahtar kelimeler: Retroçekal apandisit, Açık apendektomi, Laparoskopik apandektomi, Cerrahi

\section{ABSTRACT}

Objective: Acute appendicitis is one of the most common reasons of acute abdomen. Surgeons are increasingly preferring laparoscopic techniques in acute appendicitis. But there are still concern in cases of perforation, retrocecal appendicitis and generalized peritonitis. The aim of our study is to compare the results of open appendectomy (OA) versus laparoscopic appendectomy (LA) in retrocecal appendicitis and to determine the efficacy of laparoscopic approach in such cases.

Material and Methods: Twenty six patients were included to this retrospective study who underwent open or laparoscopic appendectomy due to acute retrocecal appendicitis. Duration of operation, length of hospital stay, complications such as wound infection, were noted and compared. Data was presented as mean \pm Standart Deviation (SD).

Results: Mean operation time for patients who underwent LA and OA were 75 \pm 20.3 SD min and 50 \pm 11.4 SD min, respectively, $p<0.001$. Mean length of hospital stay for patients who underwent LA and OA were 27.64 \pm 13 SD hours and 28.72 \pm 10.9 SD hours, respectively, $p>0.05$. The cost of operation and hospitalization was significantly lower in the OA group. Mean total costs in the OA and LA groups were $\$ 557 \pm 133.9$ SD and $\$ 806$ \pm 264.3 SD, respectively, $p<0.01$. Rate of postoperative intraabdominal abscess in LA and OA groups were similar. One patient in LA Group and four patients in OA Group had wound infection, $\mathrm{p}<0.05$.

Conclusion: LA is a safe and reliable method in the surgery of acute retrocecal appendicitis, and lower wound infection rates seems to be its advantage. Open Appendectomy is superior to Laparoscopic Appendectomy with regards to operation time and costs.

Key Words: Retrocecal appendicitis, Open appendectomy, Laparoscopy appendectomy, Surgery

Geliş Tarihi / Received: 09.07.2015

Kabul Tarihi / Accepted: 21.12.2015

Yazışma Adresi / Correspondence: Erdal Uysal

Sanko University School of Medicine, Department of General Surgery, Incilipinar Mah. Ali Fuat Cebesoy Bulv. No: 45 27090,

Sehitkamil - Gaziantep, TURKEY.

drerdaluysal@hotmail.com 


\section{INTRODUCTION}

Acute appendicitis is one of the most common reasons of acute abdomen. With the advances in minimally invasive methods, surgeons are increasingly prefering laparoscopic techniques in acute appendicitis. But there are still concern in cases of perforation, retrocecal appendicitis and generalized peritonitis. Although there are some reports that state the success of laparoscopic appendectomy in complicated cases, some authors argue that it increases morbidity in such cases (1-3). In a study that the retrocecal appendicitis position was found in 17\% (4). The aim of our study is to compare the resuls of open appendectomy (OA) versus laparoscopic appendectomy (LA) in retrocecal appendicitis and to determine the efficacy of laparoscopic approach in such cases.

\section{MATERIAL AND METHODS}

Twenty-six patients were included to this retrospective study who underwent open or laparoscopic appendectomy due to acute retrocecal appendicitis, among a total of 271 appendectomy cases, between 2011 and 2014 in our hospital. Male /female ratio were $8 / 4$ and $6 / 8$ in the LA and OA groups, respectively. All information about patients were obtained from hospital data registration and information system. Duration of operation, lenght of stay, complications such as wound infection, were noted and compared. Also, total costs for the two methods were compared. The mean cost value for each method was found by calculating the sum of fees for hospitalization, operation and management of complications.

All operations were performed by 4 surgeons who were experienced in laparoscopic surgery. Laparoscopic surgery was performed by 3 trocars, two $10 \mathrm{~mm}$ and one $5 \mathrm{~mm}$. Ligature (Ligasure, Covidien, USA) was used for the dissection of mesoappendix and appendicular artery. The base of appendix was double ligatured by endoscopic loop ligature and cut, then appendix was removed by an endobag. Classical Mc Burney incision was performed in the OA group. Mesoappendix, appendicular artery and base of appendix were ligated by absorbable sutures and then they were cut. Male /female ratio were $8 / 4$ and $6 / 8$ in the LA and OA groups, respectively.

The decision of open or laparoscopic access was made by the preference of surgeons. Two of the surgeons preferred the open method in cases that shown to have retrocecal appendicitis by preoperative $C T$, while the other 2 surgeons preferred laparoscopic surgery. A silicon drain was placed to the appendectomy region in cases with perforated appendicitis.

SPSS 13.0 statistical software program was used for statistical analysis. Chi-square test and Mann-Whitney test was used for intergroup comparison, and $p<0.05$ was accepted as significant. Data was presented as mean \pm Standart Deviation (SD). Ethical approval was not required because of the retrospective study. Ethics committee approval was not necessary because it is a retrospective study.

\section{RESULTS}

A total of 26 patients were enrolled to the study. Twelve of them underwent open, and others underwent laparoscopic appendectomy. Retrocecal appendicitis was diagnosed pre-operatively by computed tomography or intra-operatively. Decision of laparoscopic or open surgery was due to preference of the surgeon. Mean age in LA and OA Group were 25,4 10.7 SD years

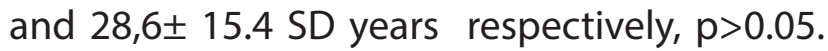
The mean preoperative WBC counts were 12.4 $\mathrm{mm} 3$ and $11.8 \mathrm{~mm} 3$ in the LA and OA groups, respectively (Table $\mathbf{1}$ ).

Table I: Data of patient undergoing open or laparoscopic appendectomy for retrocecal appendicitis

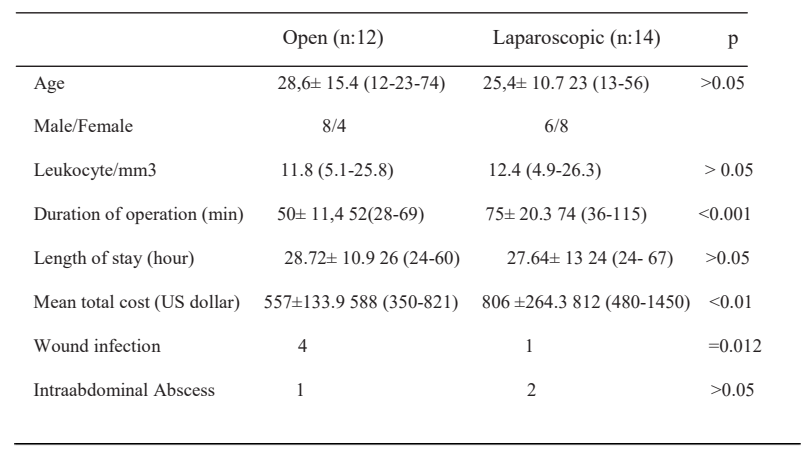

Data was presented as mean \pm Standart Deviation (SD), median (minnimum-maximum) 
Mean operation time for patients who underwent LA and OA were $75 \pm 20.3$ SD min and $50 \pm 11.4$ SD min, respectively, $p<0.001$.

Length of hospital stay for patients who underwent LA and OA were 27.64 13 SD hours and $28.72 \pm 10.9$ SD hours, respectively. There were no difference between the groups regarding to length of hospital stay, $\mathrm{p}>0.05$.

Number of patients with perforated appandicitis in LA and OA groups were 2 and 4, respectively. One patient in LA Group and three patients in OA Group had superficial wound infection, one of patients with OA had deep wound infection. There was a significant difference between the groups regarding to wound infection $(p=0.012)$. Postoperative intraabdominal abscess in LA and OA groups were 2 and 1 , respectively. There were no difference between the groups regarding to intraabdominal abscess, $p>0.05$. There was no hospital mortality in both groups. In the early postoperative period, atelectasis occured in one patient and diarrhea in another in the OA group. One patient had urinary infection in each group.

In three patients, initial LA was converted to OA due to technical difficulties. One of these due to severe adhesions related to previous surgery and other two due to hard dissections related to abscess and phlegmon. These patients were taken in the OA group.

The cost of operation was significantly lower in the OA group, $p<0.01$. Mean total costs were $\$$ $557 \pm 133.9$ SD and $\$ 806 \pm 264.3$ SD in the OA and LA groups, respectively.

\section{DISCUSSION}

Surgeons prefer to use LA ever-increasingly also in complicated appendicitis $(1,5)$. During LA, surgeons can make detailed abdominal exploration, and this helps to rule out disorders such as pelvic inflammatory disease, over cyst rupture or intraabdominal abcess that mimick acute appendicitis. It is also a good choice for treatment of such diseases in obese patients due to ease of exploration and only small incision is needed. Higher costs compared to open surgery, longer operative time and higher incidence of postoperative abscess are the drawbacks. In our study, we found significant difference between the groups in terms of operative time, it was longer in the LA group, consistent with previous reports in the literature $(6,7)$. It mostly depends of the pathology itself, and also experience of the surgeon. The duration of operation are getting shorter as there are advences in surgical techniques and instruments (8) In the present study, the longer operation durations in the LA group may be due to lack of sufficient experience in retrocecal appendicitis.

Superficial surgical site infection rate were lower in the LA cases compared to OA group in our study. All of the wound infections could be managed conservatively.

It is one of the most important advantages of laparoscopic surgery to have lower postsurgical infection rates, probably due to extraction of the specimen by endobag and leading less contamination. Nevertheless, development of postoperative intraabdominal abscess is still an important problem in some cases, and widening of contamination area by excessive dissection and irrigation was kept responsible (9, 10). In our study, postoperative intraabdominal abscess rates were similar. Percutaneous drainage was successfully performed in 2 patients for abscess. One of the intraabdominal abscess could be managed conservatively.

In cases without contamination and efficient draining, postoperative intraabdominal abscess rates are similar in LA and OA. This finding is consistent with previous study of Natajara et al, who reported that there is no significant difference between open and laparoscopic surgery regarding to postoperative intraabdominal abscess developement (11).

There was no difference between the groups regarding to length of hospital stay in our study, but some studies have stated that patients who having minimally invasive surgery are discharged earlier $(6,1,12)$.

In our study, the cost of operation and hospitalization was significantly lower in the OA group, 
consistent with the study of Kurtz et al (13). In our study, the higher cost in the laparoscopic group was primarily due to equipment and operating time. In a study that compared costs of these two methods, LA was more expensive due to surgical instruments (13), but no significant difference was found in another study (9).

Due to retrospective method, we could not compare the two surgical modalities regarding to patient comfort after discharge, need of analgesics and returning back to normal life and work. Further prospective studies are needed to compare OA and LA according to these issues. In a prospective randomized study Wei et al reported that LA is superior to OA in terms of returning back to normal life and work, (14).

LA is a safe and reliable method in the surgery of acute retrocecal appendicitis, and lower wound infection rates seems to be its advantage. OA is superior to LA with regards to operation durations and costs.

\section{REFERENCES}

1. Kirshtein B, Bayme M, Domchik S, Mizrahi S, Lantsberg L. Complicated appendicitis: laparoscopic or conventional surgery? World J Surg. 2007;31 (4):744-9.

2. Cipe G, Idiz O, Hasbahceci $M$, et al. Laparoscopic versus open appendectomy: where are we now? Chirurgia (Bucur). 2014;109(4):518-22.

3. Ingraham $A M$, Cohen $M E$, Bilimoria $K Y$, Pritts $T A$, $K o C Y$, Esposito TJ. Comparison of outcomes after laparoscopic versus open appendectomy for acute appendicitis at 222 ACS NSQIP hospitals. Surgery. 2010;148 (4):625-35.

4. Grunditz T, Rydén $\mathrm{Cl}$, Janzon L. Does the retrocecal position influence the course of acute appendicitis. Acta Chir Scand. 1983;149:707-10.

5. Ball CG, Kortbeek JB, Kirkpatrick AW, Mitchell P. Laparoscopic appendectomy for complicated appendicitis: an evaluation of postoperative factors. Surg Endosc. 2004;18 (6):969-73.

6. Li X, Zhang J, Sang L, et al. Laparoscopic versus conventional appendectomy--a meta-analysis of randomized controlled trials. BMC Gastroenterol. 2010;doi: 10.1186/1471-230X-10-129

7. Minné L, Varner D, Burnell A, Ratzer E, Clark J, Haun W. Laparoscopic vs open appendectomy. Prospective randomized study of outcomes. Arch Surg. 1997;132 (7) :708-11.

8. Bennett J, Boddy A, Rhodes M. Choice of approach for appendicectomy: a meta-analysis of open versus laparoscopic appendicectomy. Surg Laparosc. Endosc. Percutan Tech. 2007;17 (4):245-255.

9. Minutolo V, Licciardello A, Di Stefano B, Arena M, Arena G,
Antonacci V. Outcomes and cost analysis of laparoscopic versus open appendectomy for treatment of acute appendicitis: 4-years experience in a district hospital. BMC Surg. 2014;doi: $10.1186 / 1471-2482-14-14$

10. Krisher SL, Browne A, Dibbins A, Tkacz N, Curci $M$. Intraabdominal abscess after laparoscopic appandectomy for perforated appandicitis. Arc Surg 2001;136 (4):438-441.

11. Nataraja RM, Loukogeorgakis SP, Sherwood WJ, Clarke $\mathrm{SA}$, Haddad MJ. The incidence of intraabdominal abscess formation following laparoscopic appendicectomy in children: a systematic review and meta-analysis. J Laparoendosc Adv Surg Tech A. $2013 ; 23$ (9):795-802.

12. Kolovrat $M$, Lovrić $Z$, Busić $Z$, et al. Laparoscopic versus open appendectomy: our experience and literature review. Acta Med Croatica. 2012;66 (5):383-5.

13. Kurtz RJ, Heimann TM. Comparison of open and laparoscopic treatment of acute appendicitis. Am J Surg. 2001;182 (3):211214.

14. Wei HB, Huang JL, Zheng $Z \mathrm{H}$, et al. Laparoscopic versus open appendectomy: a prospective randomized comparison. Surg Endosc. 2010;24 (2):266-9. 